\title{
Woman Wisdom and the ethical vision of the book of Proverbs: An African reflection
}

\begin{abstract}
Author:
Funlola O. Olojede ${ }^{1}$

Affiliation:

${ }^{1}$ Department of Biblical and Ancient Studies, University of South Africa, South Africa

Correspondence to:

Funlola Olojede

Email:

olojefo@unisa.ac.za

Postal address:

Department of Biblical and

Ancient Studies, University of

South Africa, South Africa

Dates:

Received: 21 Oct. 2014

Accepted: 15 Feb. 2015

Published: 21 May 2015

How to cite this article:

Olojede, F.O., 2014,

'Woman Wisdom and the

ethical vision of the book

of Proverbs: An African

reflection', HTS Teologiese

Studies/Theological Studies

71(3), Art. \#2846, 6 pages.

http://dx.doi.org/10.4102/

hts.v71i3.2846

\section{Copyright:}

(c) 2015. The Authors.

Licensee: AOSIS

OpenJournals. This work is

licensed under the Creative

Commons Attribution

License.
\end{abstract}

Read online:

Scan this $Q R$

code with your smart phone or mobile device to read online.
An observable gap in scholarship is a comprehensive ethical reflection on the portrayal of wisdom as feminine in the book of Proverbs and its implication for wisdom ethics. Besides this lacuna is the observation that the few existing studies on the ethics of the book of Proverbs take their point of departure essentially from a Western conception of ethics. This article has approached the book of Proverbs from an ethical perspective and has argued that the African view of ethics has a rich quality embedded in communitarian values that can be explored heuristically to interpret the ethical vision of the book of Proverbs. Such an approach, it is suggested, has pedagogical relevance to the teaching of biblical ethics especially in Africa.

\section{Preliminary note on ethics and African ethics}

The book of Proverbs which is at the heart of what constitutes wisdom literature in the Old Testament is noted for its emphasis on moral teachings and ethical conduct. It is considered pedagogical and ethical literature (Ansberry 2011:65; Baumann 2009:15-16; Brown 1996:22; Dell 2006:19-20, 22; Sandoval 2011:641). ${ }^{1}$ Because of the centrality of ethics to the book of Proverbs, it would be helpful to consider first some theoretical issues relating broadly to ethics and to the Old Testament, before examining the place of ethics in the book of Proverbs. Ethics as a philosophical enterprise focuses on issues of morality or right and wrong conduct but, in terms of practice, ethics also refers to moral conduct. In the words of Ruggiero (2012:2), 'Ethics is the study of the choices people make regarding right and wrong'. It studies what constitutes both normal (that is, standard) and aberrant behaviour as well as the values of a given society. Ethics is also defined in the light of ethos which is seen as 'the practical side of moral behaviour, whilst ethics is viewed as 'a reflection on this practical ethos' (Baumann 2009:17). A common distinction in the study of ethics is between consequentialist (or teleological) and deontological (or command) ethics. Deontologists claim that some actions are prohibited or obligatory (that is, right or wrong) regardless of their consequences, for example, 'do not kill', whilst in consequentialist ethics, the consequence shows whether an act is good or bad (Tännsjö 2008:56). ${ }^{2}$

However, the notion of ethical relativism shows that what is considered norm or ethically binding varies from one culture to another, indicating that ethics is culture-bound (Pojman \& Fieser 2012:14; Ruggiero 2012:55). ${ }^{3}$ On the other hand, some ethicists argue that there is a basis for what is called moral objectivism which claims that some moral principles are universal and valid in all cultural environments (Pojman \& Fieser 2012:31-32). A major proponent of this kind of ethic is Hans Küng whose conception of a global ethics finds expression in the idea of the Golden Rule (Küng 1997; Ezekwonna 2005:2008; Okeja 2013:xiii). A distinction is further made between descriptive and normative or global ethics. Whilst the former is comparative in nature in that it compares various ethical systems, the latter attempts 'to develop an ethic that could be supported by any and all cultures around the globe, based on evidence of core values already present in and central to each' (Prozesky 2009:4-5). Küng's call for a global ethics which should not be understood in the sense of comparative ethics of various cultures in the world has been rejected in some circles. Nonetheless, global ethics in a normative sense is validated by some scholars and the assumption here is that African ethics can contribute to its discourse (Murove 2009:26; Prozesky 2009:3). Ezekwonna (2005:208) affirms that, 'The call for universal norms and ethics can only be justified when all cultures in equal representation enter into the dialogue'. Otherwise, who

1.For instance, Dell (2006:105) claims that the proverbs in the sentence literature ( $P r$ 10:1-22:16) had 'a broader ethical context rather than only the educational one'. On the other hand, Estes (1997:15-17) reiterates the scholarly view that Proverbs 1-9 is a didactic text that raises pedagogical and moral questions.

2.Tännsjö (2008:10-11) outlines seven points of departure when solving ethical problems, that is, seven moral theories namely utilitarianism, egoism, deontological ethics, the ethics of rights, virtue ethics, feminist ethics, and environmental or ecological ethics. The author further points out that the principles often overlap or are in conflict as the performance of an action based on one theory may infringe on another theory. However, it should be noted that other scholars categorise ethics differently. For other views, see for may infringe on another theory. However, it should be

3.In line with cultural relativism, some scholars also talk of moral relativism, which in its extreme form assumes that 'decisions about wrong and right are purely personal and subjective' (Ruggiero 2012:2). 
determines what is 'moral and ethically acceptable' becomes unclear and even one-sided.

Although ethical theories vary, especially across disciplines, for example, philosophy, psychology, medicine, etc., most of them have emerged from the developed world especially Europe and North America. This fact in recent times has led to the emergence of ethical theories from developing contexts such as Indian or Hindu, Chinese, African, and others. Specifically, the inadequacy of Western ethical models to account for the African understanding of life and morality has resulted in the call for a home-grown coherent theory of African ethics that is able to address issues of morality in various aspects of societal life on the continent including leadership, business, religion, politics, health care, and so forth (Ezekwonna 2005; Kunhiyop 2008; Bujo 2011; Okeja 2013). According to Okeja (2013):

African ethics is purely the analysis of African notions of morality. In its modern practice, it is the attempt by individual philosophers to distil, by analysis, the most fundamental moral assumptions embedded in African cultural experience. (pp. 7172; see Prozesky 2009:4)

However, because of Africa's colonial heritage, its indigenous ethics have been influenced in some sense by other cultures (Prozesky 2009:4). In Africa, moral values are communicated through customs and taboos, oral tradition, myths and legends, stories, songs, proverbs, riddles and wise sayings, and liturgy - all of which serve as foundations for African ethics $^{4}$ (Kunhiyop 2008:9-15). It goes without saying that Africa is not a monolithic entity but is marked by its cultural diversity. In spite of Africa's cultural divergence and the difficulties that are associated with what constitutes African ethics, a basic common denominator has been observed, namely, the communitarian nature of African ethics which focuses on social rather than personal ethics. The community is regarded as the starting point in African ethics because the people's moral values are rooted in the community (Bujo 2011:1-2; Ezekwonna 2005:212; Kunhiyop 2008:5; Prozesky 2009:9; Okeja 2013:69-60; 73). Bujo reiterates that:

For Black Africa, it is not the Cartesian corgito ergo sum ("I think, therefore I am") but an existential cognatus sum, ergo sumus ("I am known, therefore we are") that is decisive'. (Bujo 2011:4)

However, the emphasis on community solidarity does not necessarily imply the dissolution of individual identity. In fact:

The individual can enrich the community only when he is made a person by its individual members, so that he in his turn can share in the process by which others become persons. (Bujo 2011:93)

At the same time, the community enriches the individual so that 'the individual and the community exist in a symbiotic relationship' (Murove 2009:30; Shutte 2009:94), a point which the consequentialist ethics also takes into account.

4.The statement is not meant to suggest that moral values are not communicated through some of these channels in other cultures.
Relatedness or relationality as a central feature of African ethics is said to be expressed in the African concept of ubuntu which recognises the individual only in relation to other members of the community (Murove 2009:301-31). Ubuntu is therefore pivotal not only to Africa's community life, but also to its ethics (Okeja 2013:75). Other communitarian values which derive from ubuntu include respect, hospitality, friendliness, integrity and generosity. However, the notion of community is not limited to the visible human community; it is extended in a unique way to the invisible community of ancestors and spirits, those who are yet to be born, and even God - with all of whom the members of the human community interact in a network of relationships (Bujo 2011:2-3; Ezekwonna 2005:31-61). Relationality is expressed in the idea of the interconnectedness of different spheres of existence such as the past, present and future or of humanity and nature, as well as in the sense of 'dependence and interdependence' (Murove 2009:28-29).

Although some theorists have argued that African ethics is secular and anthropocentric or humanistic (Okeja 2013:72) rather than religious in character, others differ because the network of community relationships by which the ethics is realised is not only anthropocentric but also cosmic and theocentric (Bujo 2011:2). Whether or not African ethics is religious or secular, I will argue that the element of community in Africa's social ethics has some telling heuristic values for the interpretation of the book of Proverbs and in particular of the role of the Woman Wisdom figure in the book.

\section{Ethics in the Old Testament and in the book of Proverbs}

A number of scholars have recognised that the Old Testament contains ample resources for ethical consideration (Barton 1998, 2003; Birch 2007; Janzen 1994; Otto 1994). However, because of the multivalent nature of the voices and views expressed in the text, it has been argued that no single method of approaching the ethics of the Old Testament could be considered adequate. The ethical content of the Old Testament has therefore been investigated from divergent viewpoints, that is, from the social context, the canonical outline (studying individual books for their 'moral witness'), and as resource for modern ethical conversation (Birch 2007).

Attempts have also been made to describe the co-existence of various modes of morality in Old Testament ethics based on the Western (Socratic-Aristotelian) philosophical view of ethics mentioned earlier. Whereas the deontological or command ethics is attested mainly in the Torah, the teleological or consequentialist ethics is common in prophetic literature. Another mode the perfectionist or virtue ethics combines elements of the other two ethical modes as it, for instance, emphasises the normative and formative character of Old Testament narratives (Janzen 1994) as well as the purity of the Holiness Code. In his 2012 article, Otto provides a helpful historical outline of the various approaches to 
ethics in the Old Testament (see also Carroll and Daniel 2011:562-565). Approaching Old Testament ethics from a different perspective, Parry (2004) considers how ethics from Old Testament stories can shape the readers ethically. $\mathrm{He}$ shows that the stories have ethical values as they provide ethical models for our actions today. In other words, ethics from the Old Testament narratives can be appropriated in modern contexts.

However, ethics in wisdom literature is often related to the moral teachings in the books of Proverbs, Ecclesiastes, some Psalms, and aspects of Job. These are grounded primarily in the maxim, 'The fear of the Lord is the beginning of wisdom (knowledge)' and in the idea of reward and punishment for human action (Dell 2006:33). Although there have been a few attempts at a comprehensive study of wisdom ethics (Brown 1996, 2002), not much is available on the ethics of the book of Proverbs. Besides scattered references to the moral teachings in the book acknowledged in various studies, there appears to be no exhaustive scholarly monograph on the ethics of Proverbs. Estes (1997) has tried to analyse Proverbs 1-9 as a didactic text with educational goals in view, but the few available studies on the ethics of Proverbs as a whole are in the form of journal articles and papers and mostly focus on the unit of 1-9. The ethical features in the unit as well as the instructions in Proverbs 22:17-24:22; 30:1-14; 31 are derived from the educational context (Dell 2006:24-25, 43).

The influence of Socratic and Aristotelian ethics on Western ethics is well-known, but this influence is also reflected in the conception of Old Testament ethics, and in particular of ethics in the book of Proverbs whose final redactor is substantially dated to the Persian or Hellenistic period (see Camp 1991:303; Fox 2000:48-49; Waltke 2004:37). For instance, in the attempt to systematise the ethics of Proverbs particularly in chapter 1-9, Fox (2007) employs Socratic ethics as a model for analysing the ethics and wisdom of Proverbs. Socratic ethics sees knowledge or wisdom as a precondition for virtue, but it also claims that no one does wrong willingly, and that all virtues are one. In other words, Socrates' basic claim is that for one to be able to do good, one must have knowledge of what is good. Fox (2007:75-88) argues that there is epistemological correlation between Socrates' ethical model and the ethical vision of Proverbs, especially in chapters 1-9.

Building on Fox's argument, Ansberry (2010:160-161) agrees that wisdom indeed could be seen as a precondition for virtue. However, wisdom and intellect alone are inadequate when determining moral behaviour. For Ansberry, Aristotelian ethics which posits that wisdom must be accompanied by a virtuous disposition or good character, serves as a more viable framework for interpreting the ethical vision of the book of Proverbs as a whole:

The necessity of a virtuous disposition for moral activity is evident throughout the book of Proverbs. In fact, a virtuous disposition is the fundamental prerequisite for the acquisition of wisdom. This is apparent in the Leitmotif of the book. For the sages, the fear of $\mathrm{YHWH} \ldots$ is the beginning of knowledge. (Ansberry 2010:161; cf. Pr 1:7; 1:29; 2:5; 9:10; 30:3)

Ansberry further shows that, like Aristotelian ethics, the book of Proverbs recognises the importance of both imitation and perception in making ethical decisions. However, both Aristotelian and Proverbs ethics also diverge in certain respects. For instance, whereas Aristotle sees virtue as an intermediate state between two extremes (e.g. courage is an intermediate state between rashness and cowardice), Proverbs shows 'a static bipolar world in which the righteous are set against the wicked', the wise against the fool, the rich against the poor, and so forth (Ansberry 2010:168-169).

One must be quick to point out that although the SocraticAristotelian model employed by both Fox and Ansberry has heuristic value for ethics in the book of Proverbs, the framework is essentially Western in character. This is not to say that it is wrong to apply the framework, but given the earlier observation that moral principles and ethical values vary across cultures, the Socratic-Aristotelian model might prove to be an inadequate model in the African context where the communitarian ethics differs remarkably from the Western ethics. ${ }^{6}$ What this implies in the African context is that an adequate ethical framework for the interpretation of the ethics in the book of Proverbs, or in the Old Testament for that matter, must take into account the communitarian character of the African ethos. Besides, Baumann (2009:21-22) has noted that, 'Sapiential ethics uses different ways of argumentation and different value systems side by side', and it can be adapted to different contexts. Given the pluralistic nature of the ethical thought in sapiential literature and in the book of Proverbs, there is room also for a pluralistic approach to the ethics of Proverbs and to the way ethics from Proverbs is appropriated today. ${ }^{7}$

However, as far as context is concerned, applying a framework that employs indigenous criteria could be considered a democratic way of approaching the text, that is, one that allows the context to shape the ethical framework that is suitable to it rather than a framework that is imposed on it. Therefore an African approach does not preclude the efficacy of other models in the interpretation of the book in question. For instance, based on Western ethical models, the personification of an ideal human being in the

5.The point should also be noted that some scholars view the concept of 'the fear of YHWH' as a later addition to the book of Proverbs meant to make explicit the of $\mathrm{YHWH}^{\prime}$ as a later addition to the book of Proverbs meant to make explicit the
implicit the theology that connects wisdom to YHWH. However, it is doubtful that implicit the theology that connects wisdom to YHWH. However, it is doubtful that
this argument has much validity. As Perdue (2007:49) has noted, 'To trace the development of wisdom from an early secular tradition to a late religious one is misleading'. Besides, the notion of 'the fear of the Lord' spans the entire wisdom literature and it is generally accepted as one of the binding themes of the literature (see Ansberry 2010:161)

6.The aim here is not to pitch the Socratic-Aristotelian ethics against the proposed African communal ethics but to show the need for an African approach to biblical ethics in the African context. The Socratic-Aristotelian ethics only serves as a background for the discussion of ethics in this study.

7.The pluralistic character of ethics in general has been established. Otto (2012:4) for instance acknowledges 'the problem of a plurality of ethics, such as, bio-ethics, medical ethics, political ethics, ethics of peace, social ethics, economic ethics, legal ethics, family ethics, and gender ethics'. Accordingly, one could argue here that ethics, family ethics, and gender ethics'. Accordingly, one could argue here that
the fluidity of the approaches to ethics itself opens up the prospect of a pluralistic the fluidity of the approaches to ethics itse
approach to the study of ethics in Proverbs. 
person of Woman Wisdom, in a sense seems to resonate with the perfectionist mode of ethics, in particular if also read in relation to the ideal wife in Proverbs 31:10-31. Again, the features of a consequentialist ethics are rather strong in Proverbs, as the following proverbs confirm: 'The hardworking and diligent fellow will prosper whilst the lazy man reaps nothing' (10:4; 12:24, 27; 13:4); 'The wise will inherit glory but shame is the only promotion that fools receive' (3:35); 'He who walks in the company of the wise will be wise and the one who keeps company with fools will be destroyed' (13:20). However, these ethical approaches could prove inadequate to the African biblical reader or interpreter whose interpretation is informed by her or his context.

Thus, before I proceed to consider the possibility of a social ethics in the book of Proverbs, it would be worthwhile to mention Baumann's (2009) brief contribution to the discourse on Old Testament's sapiential ethics. Baumann, who notes that the basic morality of Old Testament wisdom is presented in the book of Proverbs, also argues that a way of systematising the ethical and other sapiential thoughts in the book is through the figure of personified wisdom in Proverbs 1-9. This is because personified wisdom represents primarily skill and ability, but it also encapsulates certain virtues such as prudence and common sense, amongst others (Baumann 2009:19). Baumann then goes on to elaborate on Kaiser's focus on the explicit ethics as well as on Zimmermann's focus on the implicit ethics of the Old Testament wisdom literature. Whilst Kaiser's explicit ethics considers basic morality embedded in virtues such as righteousness, honesty, justice, chastity, and so forth, Zimmerman systematises wisdom ethics based on the development from utilitarian and deontological to hedonistic (which maximises pleasure but minimises pain) and theonomic (which regards God as central to) ethics in the postexilic period (Kaiser 1997:115-139; Zimmermann 2002:102-122; Baumann 2009:19-22).

Furthermore, it has been established that the personification of wisdom as feminine is central to the book of Proverbs, and the female imagery is prevalent especially in Proverbs 1-9 (Dell 2002:110; Sinnott 2005:18-21, 82-87). The image of wisdom as feminine is said to tie together the divergent units of the book of Proverbs (Hunter 2006:91-107; Olojede 2011:67, 88). The assumption here is that the fundamental ideals that underlie the figure of Woman Wisdom as portrayed in Proverbs 1-9 and 30:10-31 have certain heuristic values which cannot be ignored - not only from a theological standpoint, but also from an ethical standpoint, which will be outlined in the conclusion below. More importantly, a view of Woman Wisdom from an African ethical perspective could have significant implications for the interpretation not only of sapiential ethics, but also of Old Testament ethics in general. In what follows I shall, therefore, consider elements of communitarian ethics in Proverbs and specifically in the speeches of Woman Wisdom as a heuristic device for an African understanding of the book.

\section{An African reflection on Proverb ethics as communitarian ethics}

As a result of its didactic content, the book of Proverbs is regarded as central to sapiential ethics. Again, the community context of the content is rather strong. Brown (1996) demonstrates that Proverbs:

is essentially about the journey from home to community and back again, a rite de passage that requires letting go of the parental ties of security to seek one's own security and identity through service to the community. (p. 49)

Similarly, Ansberry has observed the communal virtues inherent in Proverbs 1-9 in particular. He states that:

The lectures in Proverbs 1-9 seek to promote communal virtues and values. Their message is clear; do not steal, murder, or commit adultery; rather, pursue wisdom, justice, and marital fidelity. Together, the lectures constitute a cycle of instructions that attempt to provide the addressee with an antidote for seductive speech. (Ansberry 2011:47)

The use of proverbs and sayings as a medium of instilling moral values in African communities has been widely attested. The instructions and the sayings in the book of Proverbs also confirm the utilitarian function of proverbs in constructing ethical norms and values. The book of Proverbs could therefore be employed gainfully in the teaching of biblical ethics in Africa. However, Mugambi (1999:27) has rightly urged that, "The teaching of ethics within the context of Christianity should be conducted in such a way that it does not alienate the learners from their own heritage'. Given that several scholars have also drawn parallels between many African proverbs and the sayings in the book of Proverbs (cf. Golka 2000; Masenya 2004), engaging with African ethical values in teaching the ethics of Proverbs or of the Old Testament in Africa would appear to be reasonable. Thus, I will attempt at this point to draw a preliminary outline of the moral vision of Proverbs from an African communitarian viewpoint. This may not be regarded as exhaustive, but I will start with the whole book before narrowing the points down to Woman Wisdom:

- The dialogical nature of most of the material - the discourse setting of Proverbs 1-9 in particular - suggests a strong community interaction and network.

- Secondly, the extensive use of familial terms in the book of Proverbs points to a network of relationships which is vital to a communitarian ethics. For instance, overt and covert interactions between father and son $(1: 8,10,15$; $2: 1 ; 3: 1,11,12,21 ; 4: 10,20 ; 5: 1,20 ; 7: 1 ; 19: 27 ; 23: 15,19$, $26 ; 24: 13 ; 27: 11)$ as well as between mother and son $(1: 8$; $6: 20 ; 31: 1-2)$ point to the value of parental instructions and the importance of family and family cohesion in the ancient society. Although some scholars have suggested that father-son discourse could actually refer to a teacher-pupil kind of engagement, the maternal voice and instinct which also seem to be at play, not only in the instructions but also in the speeches of Woman Wisdom, point to a family discourse (Dell 2006:24-25, 30; 
Ansberry 2011:40-41). Other kinship terms employed in the book of Proverbs include sister (7:4), brother (17:17; $18: 9,19,24 ; 27: 10)$, kinswoman $(7: 14)$ and grandchildren $(13: 22 ; 17: 6)$.

- The emphasis on the value of friendship and good neighbourliness equally confirms the communitarian character of the moral vision of Proverbs. For example, Proverbs 27:10 says, 'Do not forsake your own friend or your father's friend, nor go to thy brother's house in the day of your calamity; better is a neighbour nearby than a brother far away' (cf. 6:1-3; 17:17; 18:24; 27:6, 9, 14, 17; $3: 28$, 29; 11:9, 12; 14:21; 16:29; 18:17; 24:28; 25:8, 9, 18; $26: 19 ; 29: 5)$.

- The principles that govern sexual ethics are based mostly on communitarian concerns, although the individual is also warned to refrain from adultery for his or her own sake (Pr 2:16-19; 6:24, 32-33). The adulterer is seen as a destroyer of the community, an agent of death (7:2427; 9:18; 23:26-28). The moral tension between wisdom and folly or between Woman Wisdom and the Strange Woman, especially in Proverbs 7 and 9, also reflects a social ethic that upholds hard work and chaste living, but looks down on laziness and sexual impropriety, amongst other vices. The bipolar division of the characters in the book, such as the righteous versus the sinner, the wise versus the foolish, the poor versus the rich, the diligent versus the lazy, the young versus the old, the ruler versus the subjects, etcetera, also points to the inclusive nature of the ethical vision of Proverbs. It is an ethics that addresses every member of the community, irrespective of their status or character.

- The repeated warning against the use of dishonest scales and diverse weights in business practices, because it is abominable to Yahweh, points to a communal value that is rooted in a theocentric ethic (Pr 11:1; 16:11; 20:10, 23). Business people are enjoined to refrain from cheating their clients and fellow citizens. Thus, issues of social justice and equity firmly embedded in the ethics of Proverbs also support a communitarian view of ethics. As Brown (1996:33) has rightly pointed out, communal (or 'community oriented') values of righteousness, justice, and equity permeate the literature. Hence, the sentence literature also mentions the relationship between the king (or ruler) and his subjects in a way that highlights these ancient Israelite communitarian values (Pr 16:10, 14; 20:2, $8,26,28 ; 22: 11 ; 24: 21 ; 25: 5,6 ; 28: 3,15,16 ; 29: 4,12,14)$. Confirming also the communitarian nature of the ethical vision of Proverbs, is the reflection on the concern for the vulnerable members of the society expressed in the various warnings against unjust treatment or belittling of the widow (15:25), the orphan (23:10), the needy and the poor $(13: 2314: 21,31 ; 17: 5 ; 19: 17 ; 21: 13 ; 22: 2,9,16,22 ; 28: 3$, $8,15,17 ; 29: 7,14 ; 30: 14 ; 31: 9,20)$.

- The fact that ethics in Proverbs is primarily related to moral teachings and that in ancient Israel, the primary locus where moral instructions were received was the home, has some telling implications for the depiction of wisdom as woman. Women (alongside men) will continue to play a pivotal role in ethical issues in the society. Virtues presupposed in wisdom's discourse - selfrestraint, (sexual) fidelity, prudence, straightforwardness, humility, discretion, hatred of evil, and fear of Yahweh, as well as moral values of righteousness, justice and equity are essentially communal (Brown 1996:40).

- The speaker in the father's lectures and in parts of the sentence literature often addresses an individual as 'my son'. Besides the formation of moral character in the young man, one of the main goals of the admonitions is to make him an upstanding member of the community (cf. Brown 1996:47). Ansberry (2011:47) confirms that the lectures in Proverbs 1-9 seek to promote communal virtues and values. For her part, Woman Wisdom addresses a plural audience in her speeches in chapters 1 , 8 and 9 . Thus, both the familial and communal values are stressed in the book.

- In her first speech in 1:20-33, Woman Wisdom is portrayed as what can be likened to the contemporary neighbourhood counsellor, social worker on a crusade, perhaps against drug addiction and violence or similar vices that affect the community as known today. She operates in the open square, in the main concourses, by the city gate. She is a preacher of righteousness who is interested in maintaining order in the community and in promoting responsible citizenship. There is no indication that the addressees are her children or close kin, which suggests that her motive is primarily for the good of the community.

- In her second speech in chapter 8, Woman Wisdom boasts of her integrity, which she invites the young men of the community to learn from and emulate. Again, she positions herself in a public space - on top of the hill, at the crossroad, by the city gate. Her honesty, prudence and uprightness are demonstrated in her leadership style and point the way to an ethics of governance. Rulers are enjoined to seek her patronage. Ansberry (2011:56) asserts that '(s)he provided the community with a family-centered social configuration, and functioned as the authoritative mediator who reconciled the chaotic sense of reality with a harmonious cosmos'. The anthropocentric character of the ethical elements in her speech $(\operatorname{Pr} 8: 4-21,32-36)$ is however balanced by a cosmic and theocentric ethical reflection on her relationship with God and the rest of creation in 8:22-31.

- In Proverbs 9:1-6, Woman Wisdom demonstrates her ability to engage with fellow members of the community. She positions herself in the highest points of the city. Here is an established upper class woman reaching out to 'street urchins' and inviting them to her banquet. Wealth in a communitarian ethics is not an end in itself but a means to an end. Woman Wisdom expends her substance for the common good. Here in Proverbs, as in the African ethic, social welfare of disadvantaged community members is not in the hands of the government, but in the hands of the good neighbour and family members. In African contexts where governments struggle to meet the needs of its deprived citizenry, empowering families to cater for the needs of their weak members may be a way forward. 
The notion of African communitarian ethics is a heuristic concept for the understanding of the social ethical vision of the book of Proverbs as outlined above. Therefore, on account of its heuristic value, the possibility of incorporating communitarian ethics into the teaching curricula on biblical ethics should be considered, especially in Africa where many theological institutions tend to rely on Western model of ethics, which their audience may not be able to relate to readily. Being a pedagogical and ethical literature itself, the book of Proverbs could serve as a launch pad for such a venture. I submit that the communitarian elements contained in African ethics could contribute positively to the on-going discourse of wisdom ethics as well as of Old Testament ethics at large, and this usefulness should be unpacked in greater detail. The insight from such ethics can also influence conversations on religious ethics in believing communities in Africa.

\section{Acknowledgements}

The background work to this study was conducted at Princeton Theological Seminary, Princeton, during September and November 2013, and was funded by a grant from the Karl Schlecht foundation through the Global Network of Research Centers. Many thanks to Hendrik L. Bosman, Michael Welker, Jacqueline Lapsley, and Juliana Claassens for their support.

\section{Competing interests}

The author declares that she has no financial or personal relationship(s) that may have inappropriately influenced her in writing this article.

\section{References}

Ansberry, C.B., 2010, 'What does Jerusalem have to do with Athens? The moral vision of the book of Proverbs and Aristotle's Nicomachean ethics', Hebrew Studies 51 of the bo

Ansberry, C.B., 2011, Be wise my son, and make my heart glad: An exploration of the courtly nature of the book of Proverbs, Walter de Gruyter, Berlin.

Barton, J., 1998, Ethics and the Old Testament, Trinity Press International, Harrisburg.

Barton, J., 2003, Understanding Old Testament ethics: Approaches and explorations, Westminster John Knox Press, Louisville.

Baumann, G., 2009, 'Wisdom and ethics - The contribution of sapiential ethics for Old Testament ethics', Verbum et Ecclesia 30(1), 15-24. http://dx.doi.org/10.4102/ ve.v30i1.61

Birch, B., 2007, 'Ethics in the OT', in K.D. Sakenfeld (ed.), The new interpreter's dictionary of the Bible, vol. 2 'D- $\mathrm{H}$ ', pp. 338-348, Abingdon, Nashville.

Brown, W.P., 1996, Character in crisis: A fresh approach to the wisdom of the Old Testament, W.B. Eerdmans, Grand Rapids.

Brown, W.P. (ed.), 2002, Character and scripture: Moral formation, community, and biblical interpretation, W.B. Eerdmans, Grand Rapids.

Bujo, B., 2011, Foundations of an African ethic: Beyond the universal claims of Western morality, transl. Brian McNeil, The Crossroad Publishing Co., New York.
Camp, C.V., 1991, 'What's so strange about the strange woman?', in D. Jobling, P.L. Day \& G.T. Sheppard (eds.), The Bible and the politics of exegesis: Essays in honor of Norman $K$ Gottwald on his sixty-fifth birthday, pp. 17-31, The Pilgrim Press, of Norman

Carroll, R. \& Daniel, M., 2011, 'Old Testament ethics', in J.B. Green (ed.), Dictionary of scripture and ethics, pp. 561-565, Baker Academic, Grand Rapids.

Dell, K.J., 2002, 'Wisdom', in J. Barton (ed.), The biblical world, vol. 1, pp. 107-128, Routledge, London. http://dx.doi.org/10.4324/9780203309490_chapter_SEVEN

Dell, K.J., 2006, The book of Proverbs in social and theological context, Cambridge University Press, New York. http://dx.doi.org/10.1017/CBO9780511488306

Estes, D.J., 1997, Hear, my son: Teaching and learning in Proverbs 1-9, Apollos, Leicester.

Ezekwonna, F.C., 2005, African communitarian ethic: The basis for the moral conscience and autonomy of the individual: Igbo culture as a case study, Peter Lang, Bern.

Fox, M.V., 2000, Proverbs 1-9: A new translation with introduction and commentary, Doubleday, New York.

Fox, M.V., 2007, 'Ethics and wisdom in the book of Proverbs', Hebrew Studies 48, 75-88. http://dx.doi.org/10.1353/hbr.2007.0028

Golka, F.W., 2000, The leopard's spots: Biblical and African wisdom in Proverbs, T \& T Clark, Edinburgh.

Hunter, A., 2006, Wisdom literature, SMC Press, London.

Janzen, W., 1994, Old Testament ethics: A paradigmatic approach, Westminster/John Knox Press, Louisville.

Kaiser, O., 1997, 'Einfache Sittlichkeit und theonome Ethik in der alttestamentlichen Weisheit', NZSThR 39, 115-139. http://dx.doi.org/10.1515/nzst.1997.39.2.115

Kunhiyop, S.W., 2008, African Christian ethics, Hippo Books, Grand Rapids.

Küng, H., 1997, A global ethic for global politics and economics, SMC Press, London.

Masenya, M., (ngwana' Mphahlele), 2004, How worthy is the Woman of Worth? Rereading Proverbs 31:10-31 in African-South Africa, Peter Lang, New York.

Mugambi, J.K.N., 1999, 'The problems of teaching ethics in African Christianity', in J.K.N. Mugambi \& A. Nasimiyu-Wasike (eds.), Moral and ethical issues in African Christianity: A challenge for African Christianity, 2nd edn., pp.11-28, Acton Publishers, Nairobi.

Murove, M.F, 2009, 'Beyond the savage evidence ethic: A vindication of African ethics', in M.F. Murove (ed.), African ethics: An anthology of comparative and applied ethics, pp. 14-32, University of KwaZulu Natal Press, Scottsville.

Olojede, F.O., 2011, 'Unsung heroines of the Hebrew Bible: A contextual theological reading from the perspective of Woman Wisdom', DTh thesis, Stellenbosch University, Stellenbosch.

Okeja, U.B., 2013, Normative justification of a global ethic: A perspective from African philosophy, Lexington Books, Lanham.

Otto, E., 1994, Theologische Ethik des Alten Testaments, Kohlhammer, Stuttgart.

Otto, E., 2012, 'Hebrew ethics in Old Testament scholarship', in D.J. Human (ed.), Psalmody and poetry in Old Testament ethics, pp. 3-13, T \& T Clark, New York.

Parry, R.A., 2004, Old Testament story and Christian ethics: The rape of Dinah as a case study, Paternoster, Milton Keynes.

Perdue, L.G., 2007, Wisdom literature: A theological history, Westminster/John Knox Louisville.

Pojma, L.P. \& Fieser, J., 2012, Ethics: Discovering right and wrong, 7th edn., Cengage Advantage Books, Boston.

Prozesky, M.H., 2009, 'Cinderella, survivor and saviour: African ethics and the quest for a global ethic', in M.F. Murove (ed.), African ethics: An anthology of comparative and applied ethics, pp. 3-13, University of KwaZulu-Natal Press, Scottsville.

Ruggiero, V.R., 2012, Thinking critically about ethical issues, 8th edn., MacGraw-Hill, New York.

Sandoval, T.J., 2011, 'Proverbs', in J.B. Green (ed.), Dictionary of scripture and ethics, pp. 641-643, Baker Academic, Grand Rapids.

Shutte, A., 2009, 'Ubuntu as the African ethical vision', in M.F. Murove (ed.), African ethics: An anthology of comparative and applied ethics, pp. 85-99, University of KwaZulu-Natal Press, Scottsville.

Sinnott, A.M., 2005, The personification of wisdom, Ashgate, Hants.

Tännsjö, T., 2008, Understanding ethics: An introduction to moral theory, 2nd edn., Edinburgh University Press, Edinburgh.

Waltke, B.K., 2004, The book of Proverbs: Chapters 1-15, Eerdmans, Grand Rapids.

Zimmermann, R., 2002, 'Theologisierung der Ethik: Relikt oder Richtmaß? Die implizite Ethik der alttestamentlichen Weisheit und ihre Impulse für die gegenwärtige Diskussion', BThZ 19, 99-124. 